\title{
RADIOACTIVITY IN ENVIRONMENT OF STARA PLANINA MOUNTAIN, IN AREA OF SUMMER SCHOOL FOR MOUNTAIN ANIMAL BREEDING
}

\author{
Borjana Vranješs ${ }^{\text {, Branislava Mitrović }}{ }^{2}$, Velibor Andrićé ${ }^{2}$ Svetlana Grdović3
}

${ }^{1} \mathrm{PhD}$ Student, Faculty of Veterinary Medicine, University of Belgrade, Belgrade, Serbia

${ }^{2}$ Faculty of Veterinary Medicine, University of Belgrade, Department of Radiology and Radiation Hygiene, Belgrade, Serbia

3Faculty of Veterinary Medicine, University of Belgrade, Department of Animal Nutrition, Belgrade, Serbia

\begin{abstract}
The aim of this paper was to investigate the activity concentration of natural radionuclides ${ }^{40} \mathrm{~K},{ }^{238} \mathrm{U}$, ${ }^{226} \mathrm{Ra}$, ${ }^{232} \mathrm{Th}$ and the anthropogenic radionuclide ${ }^{137} \mathrm{Cs}$ in the samples of soil, moss, hey, corn, yarrow, houseleek, milk and cheese. Samples were collected on Stara Planina Mountain, near the summer school for mountain animal breeding, Faculty of Veterinary Medicine, during July 2014 and June 2015. The activity concentration of natural radionuclides in soil ranged from $393-543 \mathrm{~Bq} / \mathrm{kg}\left({ }^{40} \mathrm{~K}\right), 29-57 \mathrm{~Bq} / \mathrm{kg}\left({ }^{238} \mathrm{U}\right), 25-51 \mathrm{~Bq} / \mathrm{kg}\left({ }^{226} \mathrm{Ra}\right)$, and $28-69 \mathrm{~Bq} / \mathrm{kg}$ $\left.{ }^{232} \mathrm{Th}\right)$. The highest activity concentration of ${ }^{137} \mathrm{Cs}$ in the environment of Stara Planina Mountain was measured in soil $(22 \mathrm{~Bq} / \mathrm{kg}$ ) from the area of Smilovci and moss $(26 \mathrm{~Bq} / \mathrm{kg}$ ) from the area of Kamenica. Radiocesium was also detected in houseleek $(5.7 \mathrm{~Bq} / \mathrm{kg})$, while in animal feed and dairy products the activity concentration was below the detection limit.
\end{abstract}

Key words: Radioactivity, Stara Planina Mountain, ${ }^{40} \mathrm{~K},{ }^{238} \mathrm{U},{ }^{226} \mathrm{Ra},{ }^{232} \mathrm{Th},{ }^{137} \mathrm{Cs}$

DOI: $10.21175 /$ RadProc.2016.18

\section{INTRODUCTION}

Radionuclide by process of migration and accumulation trough the soil and water reach the plants, and animals, and contribute to total irradiation of humans on the given territory [1]. From primordial radionuclides present in the soil the largest contribution to the total radioactivity is made by members of radioactive series of uranium $\left({ }^{238} \mathrm{U}\right)$, and thorium $\left({ }^{232} \mathrm{Th}\right)$, and radioactive isotope potassium $\left(4^{\circ} \mathrm{K}\right)$. Radioactive contamination of soil with ${ }^{137} \mathrm{Cs}$ is a consequence of radioactive fallout after the nuclear accident in Chernobyl 1986. Radiocesium is the most significant anthropogenic radionuclides due to its long half-life (30 years), and physiological activities similar to potassium [2]. The migration of ${ }^{137} \mathrm{Cs}$ is affected by physico-chemical characteristics of the soil [3] such as $\mathrm{pH}$, humidity, clay content presence of analogs, and the local configuration of the terrene [3], [4]. The adsorption of ${ }^{337} \mathrm{Cs}$ by soil depends on the content of organic matter. With high organic matter content the adsorption of radiocesium is reversible and cesium is more available for uptake by plants. The adsorption is decreased by presence of competing ions $\mathrm{K}$, and $\mathrm{Na}$ [4]. The food chain soil-plant-animal-humans is the main route of contamination to people with radionuclides [5]. Mosses, lichens and mushrooms are god representatives of bioindicator plants for both natural, and artificial radionuclide present in the environment. Mosses have some advantages because the accumulating capacity is higher than that of other plants and because they have a wide ecological and geological distribution, and are present during the whole year [6].

The summer school for mountain animal breading, Faculty of veterinary medicine is in the environmentally protected zone of the natural park Stara Planina. Municipality Dimitrovgrad gave the old primary school building in Gornji Krivodol to the faculty for the purpose of establishing a Teaching base. In a radius of about twenty kilometers from the educational bases there are pastures and farms of autochthonous breeds of domestic animals, where in the Gornjem Krivodol at educational base are winter ports in which the cattle is placed over winter [7]. Stara Planina Mountain is characterized by a great diversity of geological substrate, as well as areas where uranium mineralization occurs [8].

The aim of this study was to determine the activity concentration of natural radionuclides, ${ }^{40} \mathrm{~K},{ }^{238} \mathrm{U},{ }^{226} \mathrm{Ra}$

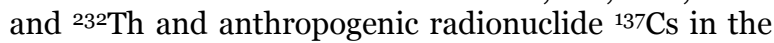
environment and the radiation risk due to exposure to terrestrial radiation at the summer school for mountain animal breading, Faculty of veterinary medicine on Stara Planina Mountain.

Samples of soil, moss, hay, corn, milk, cheese, yarrow and houseleek were collected from different locations and altitudes.

\section{MATERIALS AND METHODS}

Soil samples were collected at a depth of $0-15 \mathrm{~cm}$ from four different locations on Stara Planina

\footnotetext{
* borjanavr@gmail.com
} 
Mountain, Smilovci (710 $\mathrm{m}$ and $720 \mathrm{~m}$ above sea level), Smilovsko jezero (720 m a.s.l.), Kamenica (811 m a.s.l.), and Gornji Krivodol (835 $\mathrm{m}$ and $730 \mathrm{~m}$ a.s.l.). Samples of moss were collected from the ground, and stone at Gornji Krivodol, and Kamenica.

Samples of corn, cow's milk and cheese, goat milk and houseleek were collected from farms on area of Smilovci, and Gornji Krivodol.

Yarrow was collected in Kamenica.

Soil samples were dried at a temperature of $105{ }^{\circ} \mathrm{C}$ to constant weight, homogenised, and put in 1 l Marineli beakers.

Moss and hey samples were dried at a temperature of $105{ }^{\circ} \mathrm{C}$ to constant weight, homogenised, and then packed in containers with a content of $250 \mathrm{ml}$.

Fresh milk and cheese were packed in $1 \mathrm{l}$ Marineli beakers.

Samples were measured after four weeks, which is the time necessary for achieving radioactive equilibrium.

The activity of samples was determined by gamma spectrometry on a High Purity Germanium detector (Ortec, USA), with relative efficiency of $30 \%$ and $35 \%$, and energy resolution $1.85 \mathrm{keV} / 1332.5 \mathrm{keV}{ }^{6} \mathrm{Co}$. The counting time for samples of moss, hey, yarrow, houseless and soil was 250,000 s, and for corn, cheese, and milk 60,000 s.

Based on the results of gamma spectrometry measurements of soil radium equivalent activity (Raeq), and external hazard index $\left(\mathrm{H}_{\mathrm{ex}}\right)$ were calculated.

Radium equivalent activity was determent based on the following formula

$$
R a \text { eq }=C_{R a}+1.43 C_{T h}+0.07 C_{K}
$$

where $\mathrm{C}_{\mathrm{Ra}}, \mathrm{C}_{\mathrm{Th}}$ and $\mathrm{C}_{\mathrm{K}}$ are the activity concentrations of ${ }^{226} \mathrm{Ra},{ }^{232} \mathrm{Th}$ and ${ }^{40} \mathrm{~K}$ in $\mathrm{Bq} / \mathrm{kg}$ respectively.

When defining Raeq it is assumed that $370 \mathrm{~Bq} / \mathrm{kg}$ of ${ }^{226} \mathrm{Ra}$, or $259 \mathrm{~Bq} / \mathrm{kg}$ of ${ }^{232} \mathrm{Th}$, or $4810 \mathrm{~Bq} / \mathrm{kg}{ }^{40} \mathrm{~K}$ produce the same gamma dose [9].

External hazard index $\left(\mathrm{H}_{\mathrm{ex}}\right)$ is defined as

$$
H_{e x}=\frac{C_{R a}}{370}+\frac{C_{T h}}{259}+\frac{C_{K}}{4810}
$$

where $\mathrm{C}_{\mathrm{Ra}}, \mathrm{C}_{\mathrm{Th}}$ and $\mathrm{C}_{\mathrm{K}}$ are the activity concentrations of ${ }^{226} \mathrm{Ra},{ }^{232} \mathrm{Th}$ and ${ }^{40} \mathrm{~K}$ in $\mathrm{Bq} / \mathrm{kg}$ respectively. The value of this index must be less than unity in order to keep the radiation hazard to be insignificant [9].

\section{RESULTS AND DISCUSSION}

The main long range of Stara Planina Mountain is about 550 kilometers, and extends from Zaječar to the Black Sea. Part of this Stara Planina Mountain marks the natural border between Serbia and Bulgaria. The highest peak is Midžor, at an altitude of $2,169 \mathrm{~m}$. On the Stara Planina Mountain the climate is moderately continental, modified in relation to the altitude and position of the mountain. Stara Planina Mountain is rich in medicinal herbs, and mushrooms, and a habitat for many species of rare plants. The whole area of Stara Planina Mountain has been declared for a nature park in 1997 and thus all its reserves placed under the state protection [10]. It is built of shale, schist and limestone at the west, crystalline rocks in the most central part and of fleece in the east [11]

The results of gamma spectrometry analyses and radiation hazard parameters of soil are presented in Table 1.

The average activity concentration of natural occurring radionuclides in soil in the world, published by UNESCEAR (2000) is for ${ }^{40} \mathrm{~K} 400 \mathrm{~Bq} / \mathrm{kg},{ }^{238} \mathrm{U} 35$ $\mathrm{Bq} / \mathrm{kg},{ }^{226} \mathrm{Ra} 35 \mathrm{~Bq} / \mathrm{kg}$, and ${ }^{232} \mathrm{Th} 30 \mathrm{~Bq} / \mathrm{kg}$. The mean activity concentration of these radionuclides in soil is higher compared to the international values and is for ${ }^{40} \mathrm{~K} 461 \mathrm{~Bq} / \mathrm{kg},{ }^{238} \mathrm{U} 44 \mathrm{~Bq} / \mathrm{kg},{ }^{226} \mathrm{Ra} 40 \mathrm{~Bq} / \mathrm{kg}$, and ${ }^{232} \mathrm{Th} 50 \mathrm{~Bq} / \mathrm{kg}$.

Radium equivalent activity ( $\left(\mathrm{R}_{\mathrm{eq}}\right)$, and external hazard index $\left(\mathrm{H}_{\mathrm{ex}}\right)$ for soil are presented in Table 1 . The average value for radium equivalent activity (143 $\mathrm{Bq} / \mathrm{kg}$ ) was below the value which corresponds to a dose of $1 \mathrm{mSv}$ for the population $(370 \mathrm{~Bq} / \mathrm{kg})$. Calculated average value for the external hazard index (o.4) was less than unity and there for indicate that there is no risk of exposure to terrestrial radiation. Obtained results are similar to the results published by Tanić et al [12].

Apart from the naturally occurring radionuclides in the environment of Stara Planina Mountain artificial radiocesium is also present. Before the accident in Chernobyl (1986) the activity of ${ }^{137 C s}$ in soil in Serbia was les then $5 \mathrm{~Bq} / \mathrm{kg}$ [3]. Collected soil samples showed a variation of $137 \mathrm{Cs}$ activity concentration, lowest at Smilovsko jezero $3.1 \mathrm{~Bq} / \mathrm{kg}$, and highest 23 $\mathrm{Bq} / \mathrm{kg}$ in Smilovci. Activity concentration of ${ }^{137 \mathrm{Cs}}$ in surface layers of the soil on Stara Planina mountain in summer of 2000 was $50 \mathrm{~Bq} / \mathrm{kg}$ [3]. By comparing the result it can be concluded that even 29 years after the accident ${ }^{137} \mathrm{Cs}$ is still present in the environment but the activity has significantly decreased.

Table 1. Natural and artificial radionuclides in soil and radiation hazard parameters

\begin{tabular}{|l|l|c|c|c|c|c|c|c|c|}
\hline Sample & Location & Altitude & ${ }^{40} \mathrm{~K}$ & ${ }^{137 \mathrm{Cs}}$ & ${ }^{238} \mathrm{U}$ & ${ }^{226} \mathrm{Ra}$ & ${ }^{232} \mathrm{Th}$ & $\mathrm{Ra}$ & $\mathrm{H}_{\mathrm{ex}}$ \\
\hline \multirow{5}{*}{ Soil } & Smilovci & $710 \mathrm{~m}$ & $543 \pm 11$ & $7.5 \pm 0.2$ & $29 \pm 5$ & $25 \pm 1$ & $28 \pm 1$ & 103 & 0,3 \\
\cline { 2 - 10 } & Smilovci & $720 \mathrm{~m}$ & $410 \pm 24$ & $23 \pm 1$ & $57 \pm 6$ & $51 \pm 4$ & $69 \pm 6$ & 178 & 0,5 \\
\cline { 2 - 10 } & Smilovsko jezero & $720 \mathrm{~m}$ & $439 \pm 13$ & $3.1 \pm 0.1$ & $51 \pm 4$ & $46 \pm 3$ & $66 \pm 2$ & 171 & 0,5 \\
\cline { 2 - 10 } & Gornji Krivodol & $720 \mathrm{~m}$ & $393 \pm 20$ & $10 \pm 1$ & $49 \pm 6$ & $48 \pm 4$ & $59 \pm 5$ & 159 & 0,4 \\
\cline { 2 - 10 } & Kamenica & $811 \mathrm{~m}$ & $522 \pm 16$ & $10 \pm 1$ & $32 \pm 8$ & $28 \pm 2$ & $29 \pm 1$ & 106 & 0,3 \\
\hline
\end{tabular}


Table 2. Natural and artificial radionuclides in moss, corn, hey, dairy products, yarrow and houseleek samples

\begin{tabular}{|l|l|c|c|c|c|c|}
\hline Sample & Location & Altitude & ${ }^{40} \mathrm{~K}$ & ${ }^{137 \mathrm{Cs}}$ & ${ }^{238} \mathrm{U}$ & ${ }^{226} \mathrm{Ra}$ \\
\hline \multirow{2}{*}{ Moss from stone } & Gornji Krivodol & $730 \mathrm{~m}$ & $159 \pm 6$ & $9.1 \pm 0.4$ & $16 \pm 2$ & $6.6 \pm 0.6$ \\
\cline { 2 - 7 } & Kamenica & $811 \mathrm{~m}$ & $250 \pm 18$ & $17 \pm 1$ & $8.3 \pm 2$ & $8.1 \pm 0.8$ \\
\hline \multirow{2}{*}{$\begin{array}{l}\text { Moss from the } \\
\text { ground }\end{array}$} & Gornji Krivodol & $730 \mathrm{~m}$ & $157 \pm 6$ & $6.5 \pm 0.3$ & $<4.7$ & $7.5 \pm 0.9$ \\
\cline { 2 - 7 } Corn & Kamenica & $811 \mathrm{~m}$ & $265 \pm 10$ & $26 \pm 1$ & $18 \pm 6$ & $18 \pm 2$ \\
\hline \multirow{3}{*}{ Hey } & Smilovci & $720 \mathrm{~m}$ & $123 \pm 4$ & $<0.1$ & $<1.6$ & $<1.8$ \\
\cline { 2 - 7 } & Gornji Krivodol & $730 \mathrm{~m}$ & $94 \pm 3$ & $<0.1$ & $<1.2$ & $<1.1$ \\
\hline Cow milk & Smilovci & $720 \mathrm{~m}$ & $247 \pm 9$ & $<0.3$ & $<2.5$ & $<1.3$ \\
\cline { 2 - 7 } & Smilovci & $720 \mathrm{~m}$ & $381 \pm 12$ & $<0.3$ & $<5.7$ & $<6.7$ \\
\cline { 2 - 7 } Cow cheese & Gornji Krivodol & $730 \mathrm{~m}$ & $270 \pm 10$ & $<0.3$ & $<5.3$ & $<4.7$ \\
\hline Goat milk & Gornji Krivodol & $730 \mathrm{~m}$ & $38 \pm 2$ & $<0.1$ & $1.8 \pm 0,1$ & $<1.6$ \\
\hline Yarrow & Gornji Krivodol & $730 \mathrm{~m}$ & $68 \pm 2$ & $<0.1$ & $<0.8$ & $<0.8$ \\
\hline Houseleek & Smilovci & $720 \mathrm{~m}$ & $82 \pm 3$ & $<0.1$ & $<0.9$ & $<0.8$ \\
\hline
\end{tabular}

Results of gamma spectrometry analyses of moss, corn, hey, dairy products, yarrow, and houseleeks samples collected on Stara Planina Mountain, near the summer school for mountain animal breading, are shown in Table 2.

Mosses, lichens and mushrooms are typical representatives of bioindicator plants for radioactive contamination; by measuring the radionuclide activity levels a reliable insight into the contamination degree of ecological systems by radioactive isotopes is obtained [1], [6]. The accumulating capacity of moss is higher than that of other plants. They capture airborne particulates by both passive and active processes trough an extra cellular ion-exchange process [6]. Mosses adsorb radiocesium true the entire surface and become its reservoir [1]. Among the collected samples of moss (Table 2 ), ${ }^{40} \mathrm{~K}$ was the dominant radionuclide with the average activity of $208 \mathrm{~Bq} / \mathrm{kg}$. Activities of other natural occurring radionuclide ranged from ${ }^{238} \mathrm{U}$ 4.7-18 Bq/ kg, ${ }^{226} \mathrm{Ra}$ 6.6-18 Bq/ $\mathrm{kg}$ and ${ }^{232} \mathrm{Th} 6.3-18$ $\mathrm{Bq} / \mathrm{kg}$. The highest activity of artificial $137 \mathrm{Cs}$ was detected in the samples from Kamenica $26 \mathrm{~Bq} / \mathrm{kg}$. Average activity of ${ }^{137} \mathrm{Cs}$ in moss samples from Stara Planina, Tara and Maljen [13] were compared and presented in Table 3. Moss samples from Stara Planina Mountain have an 48-81 times lower average activity of ${ }^{137 \mathrm{Cs}}$ compared to the other two mountains.

Table 3. Average activity concentration of ${ }^{137} \mathrm{Cs}(\mathrm{Bq} / \mathrm{kg})$ in moss samples from Stara Planina, Maljen and Tara mountain

\begin{tabular}{|l|l|l|l|}
\hline Sample & Stara Planina & Maljen & Tara \\
\hline Moss & 14.7 & 1200 & 705 \\
\hline
\end{tabular}

In samples of animal feed, corn and hay, as well as animal products, milk and cheese (Table 1 ), ${ }^{\circ} \mathrm{K}$ was the dominant radionuclide, while the activity of other natural and artificial radionuclides was below the detection limit. According to the current regulations of the Republic of Serbia the limit of ${ }^{137} \mathrm{Cs}$ content in milk and dairy products is $15 \mathrm{~Bq} / \mathrm{kg}$ or $15 \mathrm{~Bq} / \mathrm{l}$ [14].

Based on this it can be conclude that milk and cheese from this area are safe for human consumption.

Yarrow (verbena, yarrow) - Achillea millefolium perennial herbaceous plant (Table 2), one of the most popular medicinal species in traditional medicine. It acts as a strong antiseptic and is used externally as a bath and balm for healing wounds or as tee for diseases of the digestive system. It grows like a weed in any dry land, roadsides, meadows and forest clearings [15]. The activity concentration of $4^{\circ} \mathrm{K}$ was $513 \mathrm{~Bq} / \mathrm{kg}$, while the activities of other natural radionuclides were below the detection limit. Low activity of $137 \mathrm{Cs} 0.5 \mathrm{~Bq} / \mathrm{kg}$ was also detected.

Houseleek (Sempervivum tectorum) evergreen dwarf perennial densely packed rosette (Table 2), with fleshy leaves from whose center during the summer develops a pink floral tree. Houseleek leaves can be used hole or just the liquor from them. It is used as a balm for hard healing wounds, burns, ear and eye inflammations and leg cramps. As tee it is used for sore throat and fever, but it also helps with intestinal worms. It grows and spreads rapidly in every light, sandy and well drained soil. It origins from high altitudes, but is widely grown in gardens. It is extremely resistant to drought, flexible and often runs wild on rocks, cracks in the walls, and often on the roofs of houses, which is how it got its name [15]. In the collected houseleek samples the activity concentration of ${ }^{40} \mathrm{~K}$ was $243 \mathrm{~Bq} / \mathrm{kg}$, while the activities of ${ }^{238} \mathrm{U},{ }^{226} \mathrm{Ra}$ and ${ }^{232} \mathrm{Th}$ were below the

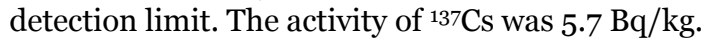

Before the accident in Chernobyl 1986 radiocesium was not detectable in the majority of the plants [3]. Nevertheless, due to the lack of literature data, on the content of natural and artificial radionuclides in plants in the area of Stara Planina Mountain, it can only be assumed that the presence of radiocesium is a direct consequence of the accident in Chernobyl.

\section{CONCLUSION}

These results, showed that the activity of natural occurring radionuclides in soil at the area of summer school for mountain animal breading, Faculty of veterinary medicine is slightly elevated compared to the global standards. However by calculating the radium equivalent activity and external hazard index, despite the increased activity, we have concluded that there is no radiation risk from exposure to terrestrial radiation. Radiocesium is still present in the environment (soil and moss), but the activity concentration in animal feed and products was below the detection limit. This shows that ${ }^{137 \mathrm{Cs}}$ is not included in the food chain. 
Acknowledgments: This paper is a part of the research done within the project "Development of technology and products based on mineral raw materials and biomass for protecting the food resources" (No. TR31003) financed by the Ministry of Education, Science and Technological Development of the Republic of Serbia (2011-2016).

\section{REFERENCES}

1. A. Čučulović and D. Veselinović, " $137 \mathrm{Cs}$ and ${ }^{40} \mathrm{~K}$ Activity Levels in Moss in Eastern Serbia", in Proceed. Ecoist, Kladovo, Serbia, 2009, pp. 37-40

2. M. Momčilović i S. Dragović, "Radioaktivnost zemljišta severozapadnog dela Stare Planine," Zbornik XXIV Simp. DZZSCG, Zlatibor, Srbija, 2007, s. 29-32. (M. Momčilović and S. Dragović, "Radioactivity of Soils from North-West Side of Stara Planina Mountain," XXIV Simp. Rad. Prot. Serb. Mntng., Zlatibor, Serbia, 2007, 29-32)

3. D. Popović i V. Spasić-Jokić, "Posledice nuklearne nesreće u Černobilju na teritoriji Republike Srbije," Vojnosan. Pregl., vol. 63, br. 5, s. 481-487, 2006. (D. Popović and V. Spasić-Jokić, "Consequences of the Chernobyl Disaster in the Region of the Republic of Serbia," Milit. Med. Exam., vol. 63, no.5, pp. 481-487, 2006

4. G. Porêba, A. Bluszcza, and Z. Śnieszko, "Concentration and Vertical Distribution of ${ }^{137} \mathrm{Cs}$ in Agricultural and Undisturbed Soils from Chechło and Czarnocin Areas", Geochronometria, vol. 22, pp. 67-72, 2003

5. B.M. Mitrović, G.Č. Vitorović i M. Lazić, "Specifična aktivnost $40 \mathrm{~K}$ i ${ }^{137} \mathrm{Cs}$ u uzorcima zemlje, sena, mahovine mleka prikupljenih sa područja Kopaonika," Vet. Žur. Rep. Srp., vol. XIV, br. 1, s. 55-61, 2014. (B. Mitrovic, G. Vitorovic and M. Lazic, "Specific Concentration of $40 \mathrm{~K}$ and ${ }^{137} \mathrm{Cs}$ in Samples of Soil, Hay, Moss, and Milk Collekted on Kopaonik Mountain", Vet. J. Rep. Srpska, vol. XIV, no.1, pp. 55-61, 2014)

Retrieved from:

http://www.virsvb.com/wp-

content/uploads/2014/11/VZurnalRS-1-2014.pdf

6. S. Grdović, G. Vitororović, B. Mitrović, V. Andric, B. Petrujkic and M. Obradovic, "Natural and Anthropogenic Radioactivity of Feedstuffs, Mosses and Soil in the Belgrade environment, Serbia”, Arch. Biol. Sci., vol. 62, pp. 301-307, 2010

7. Univerzitet u Beogradu, Fakultet veterinarske medicine. (University of Belgrade, Faculty of Veterinary Medicine) Retrieved from: http://www.vet.bg.ac.rs/uploads/files/nastavnebaze/Nastavna.baza.za.planinsko.stocarstvo.pdf
8. J. Kovačević, "Metalogenija rejona Stare Planine," doktorska disertacija, Rudarsko-geološki fakultet, Univerzitet u Beogradu, 2006. (J. Kovačević, "Metalogeny of the Stara Planina rayon," Ph.D. dissertation, Faculty of Mining and Geology, Univ. of Belgrade, 2006)

9. J. Beretka, P.J. Mathew, "Natural Radioactivity of Australian Building Materials, Industrial Wastes and Byproducts," Heal. Phys., vol. 48, pp. 87-95, Jan. 1985

10. JP za razvoj planinskog turizma Stara Planina, Knjazevac. Publ. Enter. for mountain tourism development at Stara Planina, Knjaževac)

Retrieved from:

http://www.jpstaraplanina.rs/index.php/sr/o-starojplanini/priroda

11. I. Stojanović, "Fizicko-geografska obeležja u funkciji regionalnog razvoja Balkanskog poluostrva," Master rad, Prirodno-matematički fakultet, Univ. u Nišu, Srbija, Okt. 2013. (I. Stojnaović, "Physio-Geographic Markings in Fawor of Regional Development of the Balkan Peninsula," M.S. thesis, Faculty of Nat. Sci. Math., Univ. of Niš, Serbia, Okt. 2013)

12. M. Tanić, M. Momčilović, J. Kovačević, S. Dragović and G. Bačić, "Assessment of Radiation Exposure Around Abandoned Uranium Mining Area of Stara Planina Mt., Serbia," Nucl. Techn. Rad. Prot., vol. 29, no. 1, pp. 58-66, 2014

13. B. Mitrović, G. Vitorović, D. Vitorović, G. Pantelić, and I. Adamović, "Natural and Anthropogenic Radioactivity in the Environment of Mountain Region of Serbia," $J$. Environ. Monit., vol. 11, pp. 383-388, Feb. 2009

14. Agencija za zaštitu od jonizujućih zračenja i nuklearnu sigurnost Srbije. (18.11.2011. i 6.11.2013). Sl. Gl. RS 86/2011 i 97/2013, Pravilnik o granicama sadrzaja radionuklida u vodi za piće, životnim namirnicama, stočnoj hrani, lekovima, predmetima opšte upotrebe, gradjevinskom materijalu i drugoj robi koja se stavlja u promet. (Serbian Radiation Protection and Nuclear Safety Agency. (Nov. 18, 2011 \& Nov. 6, 2011). Off. Gaz. RS 86/11 \& 97/13Rulebook on Limits of Radionuclides Content in Drinking Water, Foodstuffs, Feeding Stuffs, Medicines, Products for General Use, Construction Materials and Other Goods That are Put on Market.

15. M. Buha, Aromatične $i$ lekovite biljke u lečenju, $u$ kuhinji, u kozmetici... - uzgoj, sakupljanje, čuvanje $i$ upotreba, Niš, Srbija: FPA, 2006. (M. Buha, Aromatic and Healing Herbs in Healing, in Kitchen, in Cosmetics... - Cultivating, Gathering, Storage and Use, Niš, Serbia: FPA, 2006) 